\title{
Rethinking Resilience: Reflections on the Earthquakes in Christchurch, New Zealand, 2010 and 2011
}

\author{
Bronwyn Mary Hayward ${ }^{1,2,3}$
}

\begin{abstract}
Resilience has emerged as a policy response in an era of public concern about disasters and risks that include fear of terrorism and environmental or economic catastrophe. Resilience is both a refreshing and a problematic concept. It is refreshing in that it creates new opportunities for interdisciplinary research and vividly reminds us that the material world matters in our social lives, political economy, and urban planning. However, the concept of resilience is also problematic. Widespread, uncritical calls for greater resilience in response to environmental, economic, and social challenges often obscure significant questions of political power. In particular, we may ask, resilience of what, and for whom? My reflection here was written in the context of the ongoing grief, disruption, and community protest in my home city of Christchurch, New Zealand, a city that experienced 59 earthquakes of magnitude 5 or more, and over 3800 aftershocks of magnitude 3 or greater between September 2010 and September 2012. From this perspective, I call for expanding our political imagination about resilience, to include ideas of compassion and political resistance. In my observation, both compassion, expressed as shared vulnerability, and resistance, experienced as community mobilization against perceived injustice, have been vital elements of grassroots community recovery.
\end{abstract}

Key Words: citizenship; earthquake; political agency; resilience, social justice

\section{INTRODUCTION}

I begin this discussion acknowledging that I am standing on very shaky ground. On 22 February 2011, at 12:51 PM, Ruaumoko, the New Zealand Maori god of earthquakes, unleashed his devastating energy in my home city of Christchurch, killing 185 people, munting, or severely damaging, the homes of friends and neighbors, and destroying iconic buildings. Our university shifted into tents for 10 weeks, literally putting the concept of camping back into campus.

When disasters threaten a community, whether they are a series of slow, cumulative, almost imperceptible daily changes like a change in climate or a sudden cataclysmic event like an earthquake, these challenges test more than our physical resilience. They tear at the fabric of our economies, our democracies, and our citizenship. However, disaster also brings the opportunity for new insight and a chance to rethink basic principles. Here, I turn to rethink resilience briefly, drawing on our experiences of ongoing grief and disruption in a provincial city experiencing significant aftershocks.

New Zealand's former head of the Reserve Bank, Alan Bollard, has described the Christchurch earthquakes as "one of the biggest natural disasters in relative terms to befall an Organisation for Economic Co-operation and Development (OECD) country since World War II" (cited in Brett 2011). Residents of Christchurch, like those in Japan, who are currently struggling with their own devastating cascade of disasters, do not need to define resilience; we are simply living it. In the discussion that follows, I draw on the experiences in my community to call for expanding our political imagination about resilience to include ideas of compassion experienced as shared vulnerability, and political resistance forged in ongoing, collective struggles for social justice and alternative visions of hope.

\section{WHAT DO WE MEAN BY RESILIENCE IN THE SOCIAL WORLD?}

An important definition of resilience in environmental, urban, and disaster literature is provided by Carl Folke (2006). Folke traces the roots of resilience to the ecological literature of the 1960s and 1970s, particularly work by Holling, which examined how populations of predators and prey maintained their functions and relationships in the face of sudden shocks and disturbances across time and space. What was significant about this idea was the way it challenged previous assumptions of environmental stability. It implied that "uncertainty and surprise is part of the game and you need to be prepared for it and learn to live with it" (Folke 2006:255). Since then, "resilience thinking" has inspired a generation of researchers in fields as diverse as ecological economics and social sciences. The approach is focused less on environmental control and more on how to cope, adapt, and manage over time in an unpredictable, dynamic world (Thompson et al. 1990, Costanza et al. 1993, Perrings et al. 1995, Scoones 1999, and Adger 2000).

The lens of resilience is important. It reminds us that in our rapidly urbanizing communities, we risk losing sight of complex signals of a degrading planet, pushed to the limits of its capacity to support our growth (Jackson 2009, Clark 2011). Folke notes that Adger has used the term social resilience to highlight ways human communities can withstand a variety of external shocks to their social infrastructure (Adger 2000).

\footnotetext{
${ }^{1}$ School of Social and Political Sciences, University of Canterbury, New Zealand, ${ }^{2}$ Sustainable Lifestyles Research Group, University of Surrey, UK, ${ }^{3}$ Voices of the Future, University of Oslo, Norway
} 
Anderies et al. (2004) have introduced the term robustness to describe the ability of a system to "maintain desired system characteristics despite fluctuations."

Although he welcomes the social turn in resilience research, Folke argues that resilience is not only about persistence or robustness in the face of disturbance; it is also increasingly used as a lens to understand how communities can innovate in the face of complex fast or slow changes by drawing on institutional memory and their ability to self-organize, recombine structures and processes, renew systems, and find new trajectories. Viewed in this way, disturbance creates "opportunity for doing new things, for innovation and for development" (Folke 2006:253; see also Adger 2000, Gunderson and Holling 2002, and Berkes et al. 2003).

The Latin root for resilience is salire, to jump or spring. This concept is captured in the literature of human psychology, especially in children's research. In a review essay for the Scottish government, the children's welfare organization Barnardo's defined resilience as a cross-cultural capacity to "bounce back from adversities ... (or to maintain) competent functioning despite an interfering emotionality. A resilient child is one who exhibits positive adaptation in circumstances where one might expect, due to atypical levels of stress, a significant degradation in coping skills to take place" (Newman and Blackburn 2002:1).

However, many commentators, including the authors cited, note that the idea of resilience as a personal quality must be treated with caution. Although some stress may be characterbuilding, the expectation of personal resilience can mistakenly imply that suffering and grief are a matter of personal responsibility, or that experiencing vulnerability is an indicator of failure. Individualizing resilience can distract us from understanding resilience as a product of interpersonal relationships forged in supportive social and physical environments (Ungar 2012). The ability to make and sustain intimate friendships; the availability of support networks of friends, siblings, and other important social ties; secure attachments with adult caregivers in the early years of life; and adequate support for child health are all vital to human resilience (Bagshaw 2011). However, these qualities are also affected by social, political, and economic forces, for example, recession, unemployment, redundancy, or war, that may lie well beyond the influence and responsibility of individuals.

Given that human resilience is best understood as the interrelationships among the individuals and their community, environment, and social institutions, it has been disturbing to witness the plethora of consultancies that have sprung up in the wake of our local disaster to offer courses in personal resilience, aimed at helping employees to adapt to the "new normal" of life lived in ongoing aftershocks. The implicit subtext of many of these self-help resilience courses appears to be to restore individuals to their roles as willing workers to aid an economic recovery as quickly as possible.

Moreover, although the definitions of resilience in the ecological sciences and psychology capture something of the determination I have been privileged to observe in my community, the concept fails to capture the subtle strength of compassion I have also observed, as an acknowledgment of our shared vulnerability (Hayward 2008, Clark 2011). In my observation, emphasis on personal resilience can undermine the groundswell of community energy that was ignited in the city in the face of shared suffering. In our everyday local battles to distribute portable toilets and information, to restart businesses from shipping containers, or to engage in paper wars and play telephone tag for insurance claims, some in our community have learned a new language of liquefaction and engineering, others have shared details of shattered infrastructure and family lives; some have danced; others have withdrawn (Brett 2011).

Perhaps the most inspiring community response to the earthquakes was the formation of a large group of young volunteers, led by university student Sam Johnson. Drawing on his skills in a local musical theatre club, and on a network of friends from his university hostel, Johnson organized a remarkable Facebook campaign overnight after the September earthquake, which began to connect residents in need with students who could help. This "student volunteer army," as it became known, soon numbered 5000 young people. The army expanded even more rapidly in the week following the February earthquake, growing to 24,000 people. After the February earthquake, a core group of students coordinated 10,000 of these volunteers on the ground in neighborhood working parties that ranged in size from 10 to several hundred students daily. The students were deployed to assist by cleaning up liquefaction in the suburbs. Two and a half years later, the student army is still an active local youth trust, now experimenting with a range of social service volunteering projects beyond "shoveling silt." Others in the community responded with similar, if less sizeable, coordinated actions, often using social media to create and support baking armies and farming armies, local time banks, and residents' support organizations.

As I write, however, the city is now entering its third winter following its first earthquake, and local media reports note that stress-related depression and domestic violence have reached their highest levels on record. Such reports are worrying, particularly given that before the quakes New Zealand already lead the OECD with the highest rates of youth suicide (Hayward 2012). Many homeowners face protracted battles with local bureaucracy or insurance companies over the future of their properties, and affordable rental housing is hard to find because a conservative government initially left housing planning to "market forces." If not worried by housing strain, 
people are grieving for loss of access to shared public space because our central city remains cordoned off. Community well-being has also been significantly undermined by the public uproar that ensued after the central government decided to rush the merger and closure of many local state-funded schools, which had been important sources of support in local neighborhoods, and announced its intention to trial the introduction of new public-private charter schools. The sudden and unexpected nature of these decisions exacerbated a sense of social instability among already fragile, tired, and often low-income communities.

In rapidly changing conditions, the community has experienced life in a new way not easily captured in textbook notions of resilience, no matter how finely observed the fieldwork. Shelia Jasanoff (2010) argues that tensions inevitably arise whenever "impersonal, apolitical and universal concepts" or models of science are applied to the very political, local, and everyday experiences of human life. Anthony Giddens (1986) has also noted a long-running tension between those who think it is appropriate to apply models such as adaptation from the natural sciences to help us understand society, and social theorists, who are hostile to the use of systems theory to study communities.

In my observation, my community's experiences of life lived in ongoing aftershocks is often better captured in the tentative uncertainty and grassroots energy of new transitional architecture or street activist art that is popping up around the city, and in thoughtful essays such as those by Japanese philosopher and architect Tanizaki in his essay In Praise of Shadows, or in the political writing on failure and limits of knowledge by theorist Michael Freeden (2009). The latter's reflection on failure reminds us of the limits of expert knowledge. Nevertheless, too often a systems approach to resilience celebrates a more far-reaching, so-called transformative or comprehensive approach to decision making by professionals, in which significant long-term change is proposed for communities while they are still struggling to regain their breath and are not yet able to think of the longer term.

Furthermore, as a way of understanding community, resilience appears to be an inadequate lens through which to view questions of political power, justice, and inequality. Many of the communities that are most vulnerable to physical hazards are doubly exposed to economic and social risks (Leichenko and O'Brien 2008). However, the language of resilience too often fails to reflect the nonmaterial values of the community, such as iconic places or cultural treasures (Adger et al. 2011). Moreover, as MacKinnon and Derickson (2013) argue, resilience thinking tends to be conservative when applied to social systems, often privileging established social structures as defined by external experts (urban or disaster planners, for example). Perhaps most disconcerting, Neocleous (2013) documents the rise of resilience in psychology, management, and security literature, and argues that this trend has promoted "the resilience of state and capital" and the "individual." $\mathrm{He}$ raises important concerns about the political consequences of resilience defined in this way. He argues that implicit normative assumptions in this debate can reinforce rather than challenge socioeconomic injustices. "Good subjects will 'survive and thrive in any situation,' they will 'achieve balance' across the several insecure and part-time jobs they have, 'overcome life's hurdles' such as facing retirement without a pension to speak of, and just 'bounce back' from whatever life throws at them, whether it be cuts to benefits, wage freezes or global economic meltdown" (Neocleous 2013). The spectre that planning for "resilience" might simply secure unsustainable economic practices reminds us why it is important we not eschew normative or moral debate, but continue to ask: resilience of what, for whom?

Bonnie Honig (2009) reflects on the problem of a depoliticized approach to resilience in her powerful writing on emergency politics. With more cultural nuance than Klein's The Shock Doctrine (2008), Honig describes the broad canvas of everyday political struggle I see all around me in my community. Honig argues we need to resist the tendency to treat emergencies as exceptional events, a tendency that often legitimates the suspension of normal democratic procedures. Instead, Honig calls us to equip citizens with the tools and resources they need to assist them to fight out of submission.

Finding tools to fight out of submission is proving very important in the Christchurch context. The city has experienced the loss of an effective or meaningful democratic voice at local government level in two ways. First, despite strong local and legal objections, the central government used the earthquakes as a justification to suspend regional government elections for at least five years, retaining appointed commissioners to make decisions over regional resource use, particularly water. Second, a new centralized government department, the Canterbury Earthquake Response Authority, or CERA, has marginalized the role of locally elected urban authorities in replanning the city. Rather than reinvigorating a struggling local council by investing in staff and using advisors to lift the capacity of elected representatives, democracy was supplanted by appointed professionals. In the process, institutional memory was eroded and pre-existing lines of communication were disrupted. Most disturbing, these decisions weakened effective public accountability and scrutiny because few people in the community say that they understand who makes decisions now or how decisions are made.

Ironically, these responses are the antithesis of resilience planning (Folke 2006). The influence of international insurance companies and large businesses in the 
redevelopment of Christchurch has attracted much media and community speculation, but at the time of my writing, many people appear simply too tired or anxious about their own homes or confused about the new decision-making processes to challenge the legitimacy of decision making in a disaster (Farrell 2011).

Brown (2012) argues that resilience research is often depoliticized. She notes that the World Bank and the World Resources Institute encourage communities to become economically resilient by engaging in a market economy. However, this strategy can also undermine the resilience of indigenous or local economies. Market thinking for growth is so embedded in our policy processes that it is very difficult to embark on new trajectories of economic thought that might, for example, question the basic premises of continued material consumption and growth (Jackson 2009). Moreover, the resilience lens focuses attention on disturbance as if shocks were external to a system. In reality, our internal relationships of class, gender, and ethnic inequalities also greatly exacerbate community vulnerability (O'Brien et al. 2009). The depoliticized language of resilience and a case study approach to research can obscure the way economic and power relations are privileged across time and space and can underestimate the extent to which transformations of power will require concerted political struggle (Klein 2008, Honig 2009).

Finally, in my observation, the rhetoric of resilience is used to justify authorities making decisions quickly and measuring their impact on recovery by the speed with which the city returns to a "new normal" or experiences "certainty" as firm centralized decision making, even as many still grieve for our homes, our once beautiful city, and the ease of our past lifestyle. In reality, this political speed comes at a steep democratic price. No one denies the urgent need to house people warmly and to provide security as winter descends, or to provide new schools. However, the drive for efficiency is all too frequently used to justify expert command-and-control decision making with little or no meaningful local scrutiny or community leadership in decision making.

\section{SUMMARY: THE IMAGINATIVE POLITICS OF SHARED VULNERABILITY, SOCIAL JUSTICE, AND COLLECTIVE ACTION}

Today, citizens, everywhere, young and old, face challenging economic, social, and environmental circumstances, as they confront financial disasters and natural hazards. To address these challenges effectively, citizens will need more than resilience; we will need political imagination, creativity, and courage. Although many complain that people will not or cannot take action on long-term issues and serious threats, around the world, from Tunisia and Spain, to Greece to the pavements of my hometown, citizens, particularly young citizens, are already exercising their political agency or their ability to imagine and effect desired change in new ways. In
Christchurch, the student volunteers were driven not only by the immediate impact of an earthquake, but by a strong, youthful desire to make a difference (Hayward et al. 2011). If the student volunteer army is to engage in ongoing strong collective protest, they may yet change the direction of my community's socioeconomic development.

The potential for political action to offer resistance and new beginnings is not adequately captured in the language of resilience (Arendt 1958). However, it is the power of political imagination, protest, and agency that we need to challenge the drivers of social and economic change that threaten to destabilize our climate, increase social inequality, and degrade our environment.

Citizens' desire to make a difference is a striking feature of the new political landscape of communities everywhere, particularly youth communities (Hayward and Jackson 2011). If, as a society, we wish to support this potential for effective political action, we do not need to wait for an earthquake. Our first steps might include rethinking our employment and social policies in ways that are more just, reducing the stress of long hours of work and study, financial insecurity, and social isolation to free young people to act collectively to effect political change and to rediscover the process of forging new community visions of the common good.

Supporting effective youth-led resistance is not easy, however. David Willets (2010) has argued that the political clout of the baby boom generation at the ballot box has set the political agenda on a range of issues, including, I suggest, how we define key concepts like resilience and sustainability. It is the baby boom generation that has benefited from periods of lowcost home loans, education, low inflation, the ability to travel, and global export. It is the baby boom generation that has defined what is of value and what should be sustained or made more resilient and why. Alternatively, today, the grim economic realities of widespread youth unemployment, lack of educational opportunities, and top-down decision making could limit the opportunity for youthful citizen voices to be heard in decision making (Hayward 2012).

Willets argues that baby boomers have failed to invest in future assets and infrastructure to enable their children to enjoy similar opportunities and flexibility in their futures. At present, young citizens are struggling to find a way to have a meaningful voice in our city recovery in ways that confirm some of Willets's concerns. However, I also think Willets overlooks two fundamental contributions the baby boom generation has made to our political imagination for collective action and social justice that can help us to rethink resilience. The movement for women's rights in particular has helped enable the education of generations of young girls and women. Here in Christchurch, we have actively campaigned for recovery of local democratic voting rights by appealing to the legacy of Kate Sheppard, a local suffragette who led New 
Zealand and the world in winning rights for women to vote. Similarly, other environmental and civil rights movements, together with indigenous Maori rights and bilingual education campaigns, have the potential to inspire resilience for a more just future.

For all their contradictions, the experiences of the baby boom generation have served to remind us that human prosperity and flourishing requires more than resilience. It requires creative political imagination and agency, the ability to take action to shape our life circumstances. Significant change is unlikely to be achieved without citizen struggle to regain control of our collective political and economic life. Creating new housing and employment schemes for young people, rethinking taxation and pension schemes, new forms of social investment, and perhaps a commission for children with the ability to veto decisions that limit the life chances of future generations are just some of the changes we may need to embark on as we begin to rebuild and recreate a more inclusive city.

Here in Christchurch, many are still struggling both with the loss of much that we held dear and with the effort of advocating for the needs of the local community in the face of limited financial resources, international economic recession, loss of local democracy, and the demands of large business. Viewed from this perspective, it appears that if we wish to achieve a more significant political transformation in our future, we will need rather less resilience and more vision for compassion and social justice, achieved through collective political action.

Responses to this article can be read online at: http://www.ecologyandsociety.org/issues/responses. php/5947

\section{Acknowledgments:}

I am indebted to Katrina Brown, Neil Adger, and participants at the Blakeney workshop on resilience hosted by Tyndall University of East Anglia in 2007 and the STEPS workshop, Sussex, UK, in 2009. And thanks to Tim Jackson and Sustainable Lifestyles Research Group, colleagues in University of Surrey, UK, and to Karen O'Brien and Voices of the Future at the University of Oslo. They are in no way responsible for errors in this text, however. See also Hayward, B. 2011, "Christchurch earthquake and resilient citizenship," http://www.youtube.com/watch? $v=$ ateZ2_zOEkw. Earlier versions of this paper were also presented at the Environment and Conservation Organisations of Aotearoa New Zealand (ECO) Annual Conference, July 1 to 3, 2011, Auckland, New Zealand, and at the Design for Resilience Conference of the New Zealand Institute of Landscape Architects, 29 June to 1 July 2012, Lincoln University, New Zealand.

\section{LITERATURE CITED}

Adger, W. N. 2000. Social and ecological resilience: are they related? Progress in Human Geography 24:347-364. http:// doi: 10.1191/030913200701540465

Adger, W. N., J. Barnett, F. S. Chapin III, and H. Ellemor. 2011. This must be the place: underrepresentation of identity and meaning in climate change decision-making. Global Environmental Politics 11:1-25. http://dx.doi.org/10.1162/ GLEP a 00051

Anderies, J. M., M. A. Janssen, and E. Ostrom. 2004. A framework to analyze the robustness of social-ecological systems from an institutional perspective. Ecology and Society 9(1): 18. [online] URL: http://www.ecologyandsociety.org/ vol9/iss $1 / \operatorname{art} 18 /$

Arendt, H. 1998 (1958). The human condition. Second edition. University of Chicago Press, Chicago, Illinois, USA.

Bagshaw, S. 2011. Resiliency. Pages 78-86 in Office of the Prime Minister's Science Advisory Committee, editor. Improving the transition: reducing social and psychological morbidity during adolescence: a report from the prime minister's chief science advisor. Office of the Prime Minister's Science Advisory Committee, Auckland, New Zealand. [online] URL: http://www.pmcsa.org.nz/wp-content/uploads/ Improving-the-Transition-report.pdf

Berkes, F., J. Colding, and C. Folke, editors. 2003. Navigating social-ecological systems: building resilience for complexity and change. Cambridge University Press, Cambridge, UK; New York, New York, USA.

Berry, M. 2012. Rebuild firms 'should house staff.' The Press, 20 March. [online] URL: http://www.stuff.co.nz/the-press/ business/your-property/6601543/Rebuild-firms-should-house$\underline{\text { staff }}$

Brett, C. 2011. Christchurch three months on. Sunday Star Times, 22 May. [online] URL: http://www.stuff.co.nz/ national/christchurch-earthquake/5037194/Christchurch-threemonths-on

Brown, K. 2012. Policy discourses of resilience. Pages 37-50 in M. Pelling, D. Manuel-Navarrete, M. Redclift, editors. Climate change and the crisis of capitalism: a chance to reclaim self, society and nature. Routledge, New York, New York, USA.

Clark, N. 2011. Inhuman nature: sociable life on a dynamic planet. Sage, London, UK.

Costanza, R., L. Wainger, C. Folke, and K.-G. Mäler. 1993. Modeling complex ecological economic systems. BioScience 43(8):545-555. http://dx.doi.org/10.2307/1311949

Farrell, F. 2011. 'Free-market quake' turns citizens into assets. Christchurch Press. [online] URL: http://www.stuff.co.nz/ 
the-press/opinion/perspective/5351237/Free-market-quake-turnscitizens-into-assets

Folke, C., 2006. Resilience: the emergence of a perspective for social-ecological systems analyses. Global Environmental Change 16:253-267. http://dx.doi.org/10.1016/j.

gloenvcha.2006.04.002

Freeden, M. 2009. Failures of political thinking. Political Studies 57(1):141-164. http://dx.doi.org/10.1111/

j.1467-9248.2008.00732.x

Giddens, A. 1986. The constitution of society: outline of the theory of structuration. University of California Press, Berkeley, California, USA.

Gunderson, L. H., and C. S. Holling, editors. 2002. Panarchy: understanding transformations in human and natural systems. Island, Washington, D.C., USA.

Hannon, C., and C. Timms. 2010. Anatomy of youth. Demos, London, UK.

Hayward, B. 2008. Let's talk about the weather: decentering democratic debate about climate change. Hypatia 23(3):79-98.

Hayward, B. 2012. Children, citizenship and environment: nurturing a democratic imagination in a changing world. Earthscan/Routledge, London, UK.

Hayward, B., and T. Jackson. 2011. New graduates face a more uncertain future than ever before. The Guardian, Monday 6 June. Sustainable Business Blog. [online] URL: http://www. guardian.co.uk/sustainable-business/blog/tim-jackson-britishgraduates-green-dreams

Hayward, B., H. Donald, and E. Okeroa. 2011. Flourishing: young lives well lived in New Zealand. Pages 56-61 in United Nations Environment Programme, editor. Visions for change: country papers. Based on the Global Survey on Sustainable Lifestyles (GSSL). UNEP Task Force on Sustainable Lifestyles, Paris, France. [online] URL: http://www.unep.fr/ shared/publications/pdf/WEBx0166xPA-VisionsForChange\% 20countrypapers.pdf

Honig, B., 2009. Emergency politics: paradox, law, democracy. Princeton University Press, Princeton, New Jersey, USA.

Jackson, T. 2009. Prosperity without growth: economics for a finite planet. Earthscan, London, UK.

Jasanoff, S., 2010. A new climate for society. Theory, Culture \& Society 27(2-3):233-253. http://dx.doi.org/10.1177/02632$\underline{76409361497}$

Klein, N. 2008. The shock doctrine: the rise of disaster capitalism. Picador, New York, New York, USA.
Leichenko, R., and K. O'Brien. 2008. Environmental change and globalisation: double exposures. Oxford University Press, New York, New York, USA. http://dx.doi.org/10.1093/ acprof:oso/9780195177329.001.0001

MacKinnon, D., and K. D. Derickson. 2013. From resilience to resourcefulness: a critique of resilience policy and activism. Progress in Human Geography 37:253-270. http://dx.doi. org/10.1177/0309132512454775

Neocleous, M., 2013. Resisting resilience. Radical philosophy. RP178 March/April 2013. [online] URL:http:// www.radicalphilosophy.com/commentary/resisting-resilience

Newman, T., and S. Blackburn. 2002. Transitions in the lives of children and young people: resilience factors. Interchange 78. Barnardo's Policy, Research and Influencing Unit and the Scottish Government. [online] URL: http://www.scotland. gov.uk/Publications/2002/10/15591/11950

O'Brien, K., B. Hayward, and F. Berkes. 2009. Rethinking social contracts: building resilience in a changing climate. Ecology and Society 14(2): 12. [online] URL: http://www. ecologyandsociety.org/vol14/iss2/art12/

Perrings, C. A., K.-G. Mäler, C. Folke, C. S. Holling, B.-O. Jansson, editors. 1995. Biodiversity loss: ecological and economic issues. Cambridge University Press, Cambridge, UK. http://dx.doi.org/10.1017/CBO9781139174329

Scoones, I. 1999. New ecology and the social sciences: what prospects for a fruitful engagement? Annual Review of Anthropology 28:479-507. http://dx.doi.org/10.1146/annurev. anthro.28.1.479

Tanizaki, J. 1977. (1933) In praise of shadows. Leete's Island Books, Sedgwick, Maine, USA.

Thompson, M., R. Ellis, and A. Wildarsky. 1990. Cultural theory. Westview, Boulder, Colorado, USA.

Ungar, M. 2012. The social ecology of resilience: a handbook of theory and practice. Springer SBM, New York, New York, USA. http://dx.doi.org/10.1007/978-1-4614-0586-3

Willets D. 2010. The pinch: how the baby boomers took their children's future-and how they can give it back. Atlantic Books, London, UK. 